\title{
A Study on Timeliness of Income Recognition for Shariah Compliant Companies: A Malaysian Evidence
}

\author{
Rosmawati Haron, Siti Masnah Saringat, and Henny Hazliza Mohd Tahir
}

\begin{abstract}
This paper aims to discover the timeliness of income recognition in Malaysian's Shariah compliant companies. In Islamic teachings, weight and measurement play a significant principle in business transactions which have repeatedly emphasized by the Prophet S.A.W. Riba' or interest is forbidden in the Quran. Sunnah should be followed. Nevertheless, post-modern business world embraces International Financial Reporting Standards (IRFS) for reporting for which in contrary is insufficient to cover certain elements of Islamic practice. Hence, Shariah compliant companies are torn in between pursuing religion obligations and being internationally acceptance for compliance and reporting. This research has collected evidence from 712 companies listed in Bursa Malaysia under Shariah law, a decree that is enshrined in the Quran. We employed multiple regression method to test the samples. Malaysian capital market is chosen as our research contender due to its position as the most important Islamic finance center. In effect, even though the main driver for reporting financial statements are IFRS, we found that income recognition in these companies is not significant, an important virtue that is weighty in Shariah companies. There were few studies on Islamic financial institutions that cover different angles of income recognition for other countries. This study focus on the same scenario, yet supplemented with a study on income recognition in Shariah compliant companies in Malaysian capital market.
\end{abstract}

Index Terms-Shariah compliant, timeliness of income recognition

\section{INTRODUCTION}

The Prophet S.A.W has emphasized on honesty and kind dealings with customers. He said "The Truthful and honest merchant is associated with the Prophets, the upright and the martyrs" (Reported by Al-Tirmidhi). On other view, the Prophet also stated that "God shows mercy to a person who is kindly when he sells, when he buys and when he makes a claim" (Reported by Al-Bukhari). In fact, Prophet commanded those who made the measurements to be fair for they were entrusted to perform the affairs or otherwise expect severe consequences in the Hereafter (Reported by Al-Tirmidhi). In post-modern business world, International Financial Reporting Standards (IRFS) is adopted internationally for public listed companies for reporting purposes. Pedestal on the same standards, business performances are comparable and consistent. In contrary, the IFRS is insufficient to cover certain elements of Islamic practice [1].

Manuscript received December 14, 2012; revised February 14, 2013.

The authors are with the Universiti Teknologi MARA, Johor, Malaysia (e-mail: rosma741@johor.uitm.edu.my, sitima067@johor.uitm.edu.my, henny030@johor.uitm.edu.my).
Naturally, income recognition covers the basic principles that determine the timing of revenue, expense, profit or loss. The recognition can be made either with cash basis or accrual basis. The concepts of accrual and cash basis accounting, which we will explain herein, have pragmatic impact in Islamic teaching. Hence, based on that premises, we concur to discover on their timeliness to recognize income while juggling in between pursuing religion obligations and being internationally acceptance for compliance and reporting.

The result from this study can clearly illustrate the position of Malaysia as the most important Islamic finance center ("Banking on the Ummah," 2013) that perhaps could influence future investors who have concern on where should they place their investment. In addition, this study also contributes to the literature by examining the timeliness of Shariah compliant companies in Malaysian capital market.

\section{TIMELINES OF INCOME RECOGNITION}

Revenue recognition has been one of the most important issues confronting standard setters and accountants [2]. One of the critical issues with respect to revenue recognition is timing, i.e., the appropriate point in the sales cycle when revenue should be recognized. According to Basu [3], timeliness is defined as the extent to which current period accounting income is incorporate with current period economic income. Conservatism is conceivably can be interpreted as a way to identify current accounting income asymmetrically, nonetheless more to report economic losses rather than gain [3]. His claimed is evidenced by a study conducted by other researcher [4] who found that earnings is less elevated by good news. On the other hand, bad news are briskly affected the earnings. The reasons, as emphasized earlier by Basu [4], might due to the persistence in recognition of good news in earnings as compared to the conservative reporting of bad news.

Timeliness of earnings is an imperative element in determining the practicality of information. FASB states that "timeliness alone does not govern relevance of information, but absence of timeliness can rob information of relevance it might have had" (FASB 1980). Timeliness is of great importance because financial information users (e.g., investors, analysts, creditors, and others) need information that is relevant and useful to make economic decisions, and the disclosure of information should be timely as possible, in order not to lose the capacity to influence decision making (FASB 1980).

Thus, changes in earnings will lag the changes in stock return and current period stock returns will have relation with the future period earnings. This concept is referred to as lack of timeliness [5] 


\section{THE CONCEPT OF CASH AND ACCRUAL BASIS ACCOUNTING}

Cash basis accounting is a very simple form of accounting. Revenue is recorded when a payment is received for sale of goods or services as of that date, regardless when the sales are made. Similarly, expenses are recognized when the written cheques are cleared, again, no matter when the expenses are incurred.

On the other hand, accrual basis accounting records financial transactions based on the event rather than financial activity. This method allows the matches of revenues when they are earned, with the expenses to the period when they are incurred. While it is more complex than cash basis accounting, it provides more meaningful financial information about the business. In other words, revenues are allowed to be recognized even though the actual payment is yet to be received.

\section{INCOME RECOGNITION FROM ISLAMIC PERSPECTIVES}

Islam should be viewed as a norm of life for its teachings do not contradict by the way the economic system is organized [6]. This motion is principally to support Siddiqi [5] arguments who emphasized that human welfare can be achieved without contradiction with this worldly life and the Hereafter. As such, Siddiqi added that any ethical values and economic decisions must be morally directed, including financial reporting on economic activities. Profit making should be intended as a means for business entities to function in the economy. In worldly view, trading and manufacturing of goods and services are operated in return for profit so that they can operate and grow [7]

In Islamic teachings, weight and measurement play a significant principle in business transactions which have repeatedly emphasized by the Prophet S.A.W. Riba' or interest is forbidden in the Quran. Sunnah should be followed. Islamic finance is governed by the Shariah, a decree stated in the Quran, which prohibits interest and speculation. The stipulated income must be derived as profits from shared business risk rather than guaranteed return to avoid the elements of unfairness and exploitation. Despite of these religious constraints, Jobst [8] added that transactions in Shariah compliant companies do not diverge to the great extent from the conventional method for the system customarily involves interest-bearing debt and prediction of future income. Therefore, one of the ways to legalize lending transactions under Islamic law, asset - backed securitization is used to moderate the risk-return [6].

While post-modern business principles may evolve according to the business needs, there are three major Islamic principles that are mentioned in the Quran which relates to financial dealings and transactions namely, realization of fairness and justice, preservation of the rights and dues of all parties, and paying zakat when it is due.

The first two Islamic principles are emphasized by the Holy Quran. As indicated in Al-Baqarah, verse 282, Muslims are required to write down faithfully and precisely financial transactions involving debts or future obligations. "O you who believe! When you deal with each other, in transactions involving future obligations in a fixed period of time, reduce them to writing" and "Let a scribe write down faithfully as between the parties" (QS2:282)

Hence, based on the above verses, transactions between human beings must be fair and just. Therefore, accounting information is expected to fill the needs of those who required the information for the preparation of financial statements is not only accountable to business owners or shareholders, but also to fulfill the ultimate accountability to Allah [8]. Into the bargain, having accurate and just recording is essential in order to allow the followers to determine the amount of Zakat.

\section{The Methodology AND HyPOTHESIS DEVELOPMENT}

To satisfy our research objective, we have adopted an equation introduced by Basu [4]:

$$
E Y_{i, t}=\beta_{1}+\beta_{2} R_{i, t}+\beta_{3} D+\beta_{4} R_{i, t} D+e .
$$

where

\begin{tabular}{|l|l|l|}
\hline$E Y_{t}$ & $=$ & Earnings yield measured by $E P S_{t} / P_{t-1}$ \\
\hline$R_{t}$ & $=$ & Return measured by $\left(P_{t}-P_{t-1}\right) / P_{t-1}$ \\
\hline$D$ & $=$ & $\begin{array}{l}\text { Dummy variable, which takes a value of } 1 \\
\text { if } R_{t} \text { is negative }\end{array}$ \\
\hline$R_{t} D$ & $=$ & $\begin{array}{l}\text { Incremental responsiveness of earnings to } \\
\text { negative return }\end{array}$ \\
\hline$e$ & $=$ & Error term \\
\hline
\end{tabular}

While $\beta_{2}$ remains as the coefficient that determines the timeliness, we have hypothezed that the augmentation sensitivity of market return if $\beta_{2}=1$, the companies recognized their revenues timely while $\beta_{2}=0$ indicates not. Based on Islamic law, we hypothesized that our sample should not reveal timeliness in income recognition. We tested our hypothesis with a sample of 712 Shariah compliant companies in Malaysian capital market over the period of 2006 - 2011. We trimmed down the samples to 579 companies, due to the unavailability of data, leading to 3,474 firm-years observation.

\section{THE FINDINGS AND DISCUSSIONS}

Based pooled sample on Table I, we found that the slope coefficient $\beta_{2}$ from regression is negative $\left(\beta_{2}<1\right)$ and not significant at any level of significance. Therefore it can be concluded that Shariah compliant companies in Malaysia do not practice timeliness in income recognition. The result is inconsistent with findings other researchers [9]. The sample is divided into two by introducing dummy variables to indicate whether the change in return is positive or negative. The incremental response of earnings to negative return relative to positive return as measured by $\beta_{4}$ is positive but not significant at any level of significance. It shows that asymmetric timeliness seems not to be important feature of financial reporting for Shariah compliant companies in Malaysia. Other research [9] reported the same findings for sample from France, Norway, Sweden and Switzerland. The model $R^{2}$ is only $0.1 \%$, which indicates that the explanatory 
power of the model does not really account for variation in the earnings.

TABLE I: REGRESSION RESULT OF TIMELINESS IN INCOME RECOGNITION

\begin{tabular}{|l|l|c|c|c|c|c|}
\hline Year & Firm-years & $\beta_{1}$ & $\beta_{2} \mathrm{R}_{\mathrm{i}, \mathrm{t}}$ & $\beta_{3} \mathrm{D}$ & $\beta_{4} \mathrm{R}_{\mathrm{i}, \mathrm{D}} \mathrm{D}$ & $\mathrm{R}^{2}$ \\
\hline $\begin{array}{l}\text { Pooled } \\
\text { sample }\end{array}$ & 3,474 & -0.089 & -0.192 & $\begin{array}{l}0.11 \\
2\end{array}$ & 2.164 & $\begin{array}{l}0.00 \\
1\end{array}$ \\
\hline
\end{tabular}

Note: The table indicates significance at $1 \%(* * *), 5 \%(* *)$ and $10 \%(*)$ levels of confidence

\section{CONCLUSIONS}

Cash basis of accounting maybe the most appropriate method to recognize revenue for its reliability to recognize income is increased because transactions are recorded only when all phases of transactions are complete, even though an Islamic teaching does not repudiate the importance of accrual accounting. The practice of income recognition for Shariah compliant companies in our samples is nevertheless, does not contradict with Islamic teachings and values, a result that might alleviate the investors of Shariah compliant companies. Perhaps, with these findings, Shariah compliant for business dealings might become a social responsible to address needs of investors' cultures and beliefs.

\section{ACKNOWLEDGEMENT}

A thank you to the management of Accounting, Business and Economy Research Center (ABERC) of Universiti Teknologi MARA, JOHOR and Accounting Reserch Institute (ARI) and Research Management Institute (RMI) for their belief and continuous support.

\section{REFERENCES}

[1] R. Ball, A. Robin, and J. S. Wu, "Incentive Versus Standards: Properties of Accounting Income in for East Asian Countries," Journal of Accounting and Economics, vol. 36, pp. 235-270, 2003.

[2] "Banking on the Ummah," The Economist, January 5, 2013.

[3] S. Basu, "The Conservatism Principle and the Asymmetric Timeliness of Earnings," Journal of Accounting and Economics, vol. 24, pp. 3-37, 1997.

[4] S. Maheshwar, A. Krishnamoorthy, W. Berry, and J. Stone, "Lack of timeliness in Reported Earnings and Fundamental Financial Statement Analysis," Journal of Economics and Finance, vol. 4, no. 2, pp. 21-31, 2003.

[5] M. N. Siddiqi, The Economic Enterprise in Islam, 1972.

[6] A. R. A. Rahman, "Accounting Regulatory Issues on Investments in Islamic Bonds," International Journal of Islamic Financial Services, vol. 4, no. 4, 2003.

[7] A. J. Ali, A. A. Aali, and A. A. Owaihan, "Islamic Perspective on Profit Maximization," Journal of Business Ethics, 2012.

[8] A. A. Jobst, "The Economics of Islamic Finance and Securitization," Journal of Structured Finance, vol. 12, no. 1, 2007.

[9] Y. Zhang, "Revenue Recognition Timing and Attributes of Reported Revenue: The case of Software Industry's Adoption of SOP 91-1,' Journal of Accounting and Economics, vol. 39, pp. 535-561, 2005.
[10] I. Raonic, S. McLeay, and I. Asimokopoulos, "The Timeliness of Income Recognition by European Companies: An Analysis of Institutional and Market Complexity," Journal of Business Finance and Accounting, vol. 31, no. 1-2, 2004.

[11] Y. Ding and H. Stolowy, "Timeliness and Conservatism: Changes Over Time in the Properties of Accountng Income in France," Review of Accounting and Finance, vol. 5, no. 2, pp. 92-107, 2006.

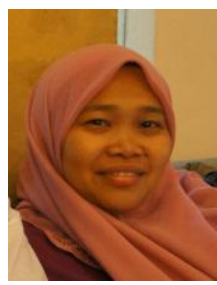

Rosmawati Haron is an accounting lecturer specialising in Financial Reporting at the Universiti Teknologi MARA, Johor, Malaysia. Her career as a lecturer began in 2008 after being exposed in local automotive industries for 12 years. Rosmawati has developed an exceptional background in cost management accounting and cost reduction activities based on excellent team work and an ability to make the best possible use of her personal network. Rosmawati has a Bachelor in Commerce from the University of New England, Australia and Master in Accounting from the university where she is currently working. Based on her immense working experience, she was appointed as the Coordinator for Industrial Training Program for accounting undergraduate students since 2009. At present, Rosmawati has developed a keen sense in Financial Criminology and Forensic Accounting in Public Sector. She is a fellow of the Accounting, Business and Economy Research Center (ABERC) in Universiti Teknologi MARA, Johor and is an active member for Accounting Research Insitute (ARI).

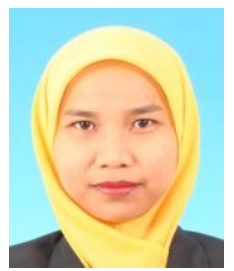

Siti Masnah Saringat is an accounting lecturer specialising in Financial Accounting and Taxation in the Universiti Teknologi MARA, Johor, Malaysia. Her career as a lecturer began in 2007 after involved in the manufacturing and service industries for 10 years. She has developed an exceptional background in cost reduction through the development and implementation of integrated system within the company. Siti Masnah has a Bachelor in Accounting from Universiti Utara Malaysia and Master in Accounting from Universiti Teknologi MARA, Johor, Malaysia. At present, Siti Masnah has developed a keen interest in corporate social responsibility. She is a fellow of the Accounting, Business and Economy Research Center (ABERC) in Universiti Teknologi MARA, Johor.

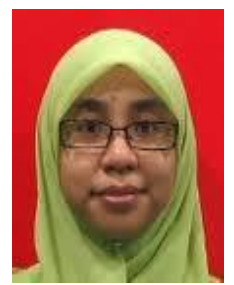

Henny Hazliza Mohd Tahir is an accounting lecturer specialising in Auditing and Social Reporting at the Universiti Teknologi MARA, Johor, Malaysia. Her career as a lecturer began in 2008 after being exposed as auditor for 2 years. Henny Hazliza has developed an exceptional background auditing and assurance services and due diligence audit based on excellent team work and an ability to make the best possible use of her personal network. Henny Hazliza has a Bachelor in Accountancy and Master in Accountancy from the Universiti Teknologi Mara. Based on her immense working experience, she was appointed as the Course Coordinator for accounting undergraduate students since 2011. At present, Henny Hazliza has developed a keen sense in Islamic Accounting and green Accountig. She is a fellow of the Accounting, Business and Economy Research Center (ABERC) in Universiti Teknologi MARA, Johor and is an active member for Accounting Research Insitute (ARI). 